\title{
Community Compliance Level to Health Policy to Prevent Covid-19
}

\author{
Alfisa Her Bening ${ }^{1}$, Dian Hudiyawati ${ }^{2}$ \\ ${ }^{1}$ Student School of Nursing, Faculty of Health Sciences, Universitas Muhammadiyah Surakarta, Sukoharjo 57162 , \\ Jawa Tengah, Indonesia \\ ${ }^{2}$ School of Nursing, Faculty of Health Sciences, Universitas Muhammadiyah Surakarta, Sukoharjo 57162, Jawa \\ Tengah, Indonesia \\ 1j210191231@ums.ac.id *; ${ }^{2}$ dian.hudiyawati@ums.ac.id \\ *Corresponding author
}

Submission date: 16 Februari 2021, Receipt date: 28 Maret 2021, Publication date: 1 April 2021

\begin{abstract}
This study identified the level of compliance toward the COVID-19 prevention health protocols among the Tegalrejo District community. This descriptive study used an accidental design, distributing closed questions in a google form questionnaire accidentally to 110 respondents on social media. Data were analyzed univariately by calculating the frequency, percentage and cross tabulation. The results from this study describe that most of the respondents did not comply with the COVID-19 prevention health protocol (95.5\%) because there had been a cognitive bias in the community.
\end{abstract}

Keywords: compliance, health policy, covid-19

\section{INTRODUCTION}

In March 2020 WHO declared COVID-19 caused by Severe Acute Respiratory Syndrome Corona-virus-2 (SARS-CoV-2) as a pandemic (Andrews et al., 2020). In response to this situation, based on WHO recommendations Indonesian government issued a policy through Minister of Health Decree No. 413 of 2020 be health policies to minimize the transmission of COVID-19containing physical distancing, hand hygiene, self-isolation, the use of masks and cough and sneeze etiquette (Kemenkes RI, 2020). The success of this policy is highly dependent on people's attitudes towards compliance (Yanti et al., 2020).

The results of the report from Badan Pusat Statistik (2020) obtained data from respondents who know about health policies to prevent the transmission of COVID-19, there are $72 \%$ of respondents who comply with the policy physical distancing, $80.2 \%$ of respondents comply with hand hygiene and the policy of using masks. The majority of respondents have complied with the established policies regarding physical distancing, hand hygiene, use of masks, self-isolation and cough etiquette.

However, in research conducted on STIA Muhammadiyah Selong students, it was found that the majority of respondents had not been maximized in making efforts to prevent the transmission of COVID-19, especially in the application of physical 
distancing (Yuniarti \& Hartati, 2020). Researchers also often find people in Tegalrejo Magelang District who have not complied with health protocols.

Based on the description above, there are differences in data regarding the level of compliance with established health policies. Therefore, in the current study, he wanted to identify the level of public compliance with the health policy for preventing COVID-19in Tegalrejo Magelang District. This study aims to describe the level of community compliance with health policies to prevent the transmission of COVID-19in Tegalrejo Magelang District based on gender, age, education and economy.

\section{RESEARCH METHODS}

This research used descriptive analysis method. Researchers took the population of the Tegalrejo Magelang District community. The number of respondents in this study were 110 respondents who were taken by accidental sampling technique. This study uses a single variable, namely public compliance with COVID-19preventive health policies.

Data were collected using an online questionnaire in the form of google form and distributed on 5-19 November 2020 to 7 villages in Tegalrejo District. The measuring instrument of this study consisted of 2 types of questionnaires. The first questionnaire contains demographic aspects of participants including age, gender, occupation, education level, income and sources of information on COVID-19. The second questionnaire is a compliance questionnaire consisting of 22 questions and has been compiled based on the health policy in the Minister of Health Decree No. 413 of 2020. The measurement of compliance uses the scale Guttman, if the respondent answers correctly is given point 1 and if the answer is wrong it is given point 0 . Respondents are categorized as obedient if they get a value of 22 and disobedient if it gets a value $<22$. The questionnaire in this study has been tested for validity and reliability with the results of thevalue Pearson correlation of 0.73 and the result of Cronbach alpha of 0.89 .

Data were analyzed using univariate analysis to determine the level of community compliance by calculating the frequency distribution and percentage. Data presentation is presented in the form of diagrams, tables, or graphs with the aim of knowing the level of compliance of respondents. This study uses the ethical principles of informed consent, anonymity and confidentiality.

\section{RESULTS AND DISCUSSION}

The results based on Figure 1, compliance to health policies for prevention of COVID-19can be seen from 110 respondents, there are 105 respondents $(95.5 \%)$ who do not comply with the health policy to prevent COVID-19and 5 respondents $(4.5 \%)$ comply with the health policy for preventing COVID-19.

From table 1, the majority of respondents are 26-35 years old (29.1\%), the majority of respondents are female, 76 respondents $(69.1 \%), 39$ respondents $(35.5 \%)$ high school / vocational education (35.5\%), work as civil servants / private 38 respondents $(34.5 \%)$, the majority of income Rp. 0 - Rp. 2,042,200 as many as 63 respondents $(57.3 \%)$ and the majority of information sources about COVID-19 came from social media. 
The results of the questionnaire for compliance and demographic characteristics of respondents including age, education level, occupation, gender, income and sources of information regarding COVID-19 in this study obtained the following results:

Table 1. Distribution of Respondents' Demographic

\begin{tabular}{|c|c|c|c|c|c|c|}
\hline \multirow[t]{3}{*}{ Characteristics of Respondents } & \multicolumn{4}{|c|}{$\begin{array}{l}\text { Compliance with Health } \\
\text { Protocols }(\mathrm{n}=110)\end{array}$} & \multirow{2}{*}{\multicolumn{2}{|c|}{ Total }} \\
\hline & \multicolumn{2}{|c|}{ Compliance } & \multicolumn{2}{|c|}{ Disobedient } & & \\
\hline & $\mathbf{n}$ & $\%$ & $\mathbf{n}$ & $\%$ & $\mathbf{n}$ & $\%$ \\
\hline \multicolumn{7}{|l|}{ Age } \\
\hline 15-25 years (Late adolescence) & 2 & 1.8 & 28 & 25.5 & 30 & 27.3 \\
\hline $26-35$ years (Early adults) & 2 & 1.8 & 30 & 27.2 & 32 & 29.0 \\
\hline $36-45$ years (Late adults) & 1 & 0.9 & 27 & 24.5 & 28 & 25.5 \\
\hline 46-55 years (Early seniors) & 0 & 0 & 18 & 16.4 & 18 & 16.4 \\
\hline 56-65 years (Late elderly) & 0 & 0 & 2 & 1.8 & 2 & 1.8 \\
\hline \multicolumn{7}{|l|}{ Gender } \\
\hline Male & 0 & 0 & 34 & 30.9 & 34 & 30.9 \\
\hline Female & 5 & 4.5 & 71 & 64.6 & 76 & 69.1 \\
\hline \multicolumn{7}{|l|}{ Education } \\
\hline Elementary School & 0 & 0 & 9 & 8.2 & 9 & 8.2 \\
\hline Junior High School & 0 & 0 & 15 & 13.6 & 15 & 13.6 \\
\hline Senior High School & 1 & 0.9 & 38 & 34.5 & 39 & 35.5 \\
\hline Associate Degree & 2 & 1.8 & 14 & 12.7 & 16 & 14.5 \\
\hline Bachelor & 2 & 1.8 & 29 & 26.4 & 31 & 28.2 \\
\hline \multicolumn{7}{|l|}{ Occupation } \\
\hline Student / College Student & 0 & 0 & 12 & 10.9 & 12 & 11.0 \\
\hline Farmers/ Traders/ Laborers/ Freelancers & 0 & 0 & 25 & 22.7 & 25 & 22.7 \\
\hline Entrepreneurs & 2 & 1.8 & 8 & 7.2 & 10 & 9.1 \\
\hline Public / private employees & 3 & 2.7 & 35 & 31.8 & 38 & 34.5 \\
\hline Others & 0 & 0 & 25 & 22.7 & 25 & 22.7 \\
\hline \multicolumn{7}{|l|}{ Income } \\
\hline IDR 0 - Rp 2,042,200 & 0 & 0 & 63 & 57.3 & 63 & 57.3 \\
\hline$>$ IDR 2,042,200 & 5 & 4.5 & 42 & 38.2 & 47 & 42.7 \\
\hline \multicolumn{7}{|l|}{ Information about COVID-19 } \\
\hline $\begin{array}{l}\text { Mass Media (Newspapers / Books / } \\
\text { Magazines) }\end{array}$ & 2 & 1.8 & 1 & 0.9 & 3 & 2.7 \\
\hline Electronic Media (Radio / TV) & 1 & 0.9 & 38 & 34.5 & 39 & 35.5 \\
\hline $\begin{array}{l}\text { Social Media (Instragram / twitter / } \\
\text { facebook / whatsapp) }\end{array}$ & 2 & 1.8 & 62 & 56.4 & 64 & 58.2 \\
\hline Relatives / family & 0 & 0 & 3 & 3.7 & 3 & 2.7 \\
\hline Others & 0 & 0 & 1 & 0.9 & 1 & 0.9 \\
\hline
\end{tabular}

Table 2. Frequency Distribution of Compliance with COVID-19 Prevention Policy $(\mathrm{n}=110)$

\begin{tabular}{lcccc}
\hline \multirow{2}{*}{$\begin{array}{c}\text { Health Policy for Prevention } \\
\text { COVID-19 }\end{array}$} & \multicolumn{2}{c}{ Compliant } & \multicolumn{2}{c}{ Disobedient } \\
\cline { 2 - 5 } & $\mathbf{n}$ & $\mathbf{\%}$ & $\mathbf{n}$ & $\mathbf{\%}$ \\
\hline Physical Distancing & 78 & 70.9 & 32 & 29.1 \\
Hand-hygiene & 98 & 89.1 & 12 & 10.9 \\
Masks & 104 & 94.5 & 6 & 5.5 \\
Self-Isolation & 89 & 80.9 & 21 & 19.1 \\
Cough \& Sneeze Ethics & 87 & 79.1 & 23 & 20.9 \\
\hline
\end{tabular}




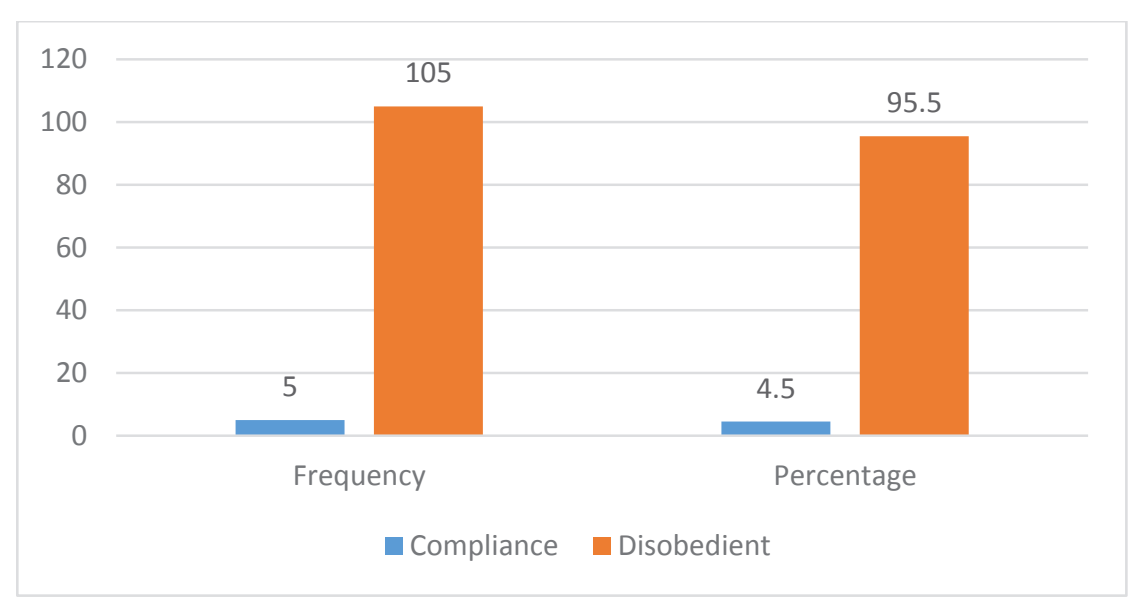

Figure 1. Respondents' Compliance

Based on the research, it was found that the majority of respondents did not comply with the health policy for preventing COVID-19. This result is in contrast to research in Riau Islands Province which was carried out at the beginning of the pandemic, in which the majority of respondents obeyed established health policies in the form of physical distancing (Martias et al., 2020). This is in line with the social psychology theory which states that high threats can increase the obedience and compliance of an individual in carrying out the desired behavior (Sari, 2018). Meanwhile, this research was conducted in November or the eighth month of the pandemic, where the condition of the community was exposed to massive information about COVID-19which was random (impulsive) and always changing or inconsistent.

The amount of information that can be obtained through various media and easily accessible causes the potential for greater cognitive bias, one of which is optimistic bias (Agung, 2020). Optimistic bias is the tendency to judge that they are not at risk of disease compared to other people (Brannon et al., 2018). So that this reduces public compliance with policies to prevent transmission of COVID-19.

Based on the age characteristics, the majority of respondents who adhere to the health protocol are in their late adolescence and adulthood. Based on research by Yanti et al., (2020) in 34 provinces in Indonesia where the majority of respondents are in adulthood. The adult age group is a group that is at a very productive age and has high mobilization (Utami et al., 2020).

The majority of the respondents in this study had a high school/ vocational education, in contrast to the respondents in the Riau Islands, where the majority had a university education. This is in accordance with what is stated in the Handbook of Health Economics written by Cowell which states that individuals who have higher education levels have healthier conditions and more often adopt healthier living behaviors (Yanti et al., 2020). The relationship to individual knowledge in receiving information so that it affects individual behavior (Hudiyawati \& Rizki, 2018). There is a relationship between knowledge and community compliance in implementing COVID19preventive health policies (Sari \& 'Atiqoh, 2020). 
Based on gender characteristics, the majority of respondents are women who are obedient to implementing health policies. This is in accordance with research in Henan, China which states that female respondents practice self-protection more often to prevent transmission of COVID-19 (Zhang et al., 2020). This can happen because men tend to be more aggressive, tough and dominant while women are more obedient, affectionate and gentle, this causes the intensity of obedience in women to be higher than men (Nuqul, 2016).

Based on the characteristics of sources of information regarding COVID-19, the majority of respondents who obeyed health protocols received information through mass media and social media. This is in line with Sampurno et al. (2020) statement if internet and informatics interventions have the ability to help someone modify behavior to improve health, in this case it is applied as a behavior to prevent COVID-19 transmission.

Based on the frequency distribution of respondents' compliance with the health policy for prevention of COVID-19, it was found that the majority of respondents had implemented a policy of using masks in accordance with the recommendations of Kemenkes RI (2020), namely when doing outdoor activities and interacting with other people whose health is unknown, the public is obliged to wear a mask that covers the nose and mouth. The results of this study are in line with research which states that the majority of respondents in Ngronggah have complied with the policy of using masks (Sari \& 'Atiqoh, 2020). Based on the observations of researchers, the compliance of the Tegalrejo District community in using masks is very high because there are punishment for people who do not use masks by local policy makers. This is in line with social psychology theory which believes that high threats can increase an individual's compliance (Sari, 2018).

But on the other hand, the results of this study show that there are still many respondents who have not complied with the physical distancing policy by maintaining a minimum distance of 1 meter, not making physical contact such as hugging and shaking hands. Transmission of COVID-19 is more often transmitted from sufferers to other people through droplets within a short distance or 1 meter (Gorbalenya et al., 2020). Based on researchers' observations, this occurs because many people do not understand the risks of COVID-19 and there are still many people who are indifferent to health policies on the grounds of job demands. Based on the results of research by Wulandari (2015) it is stated that the non-compliance of an individual can be caused by knowledge factors.

\section{CONCLUSION}

Based on the results of the research and discussion, it can be concluded that the level of compliance of the community in Tegalrejo Magelang District with the health policy for the prevention of COVID-19, the majority of respondents did not comply with the established health protocols this was due to cognitive bias in the community. The results of this study are likely to change in the future and cannot be generalized in other areas. 


\section{REFERENCES}

Agung, I. M. (2020). Memahami pandemi covid-19 dalam perspektif psikologi sosial. Psikobuletin:Buletin Ilmiah Psikologi, 1(2), 68-84.

Andrews, J. L., Foulkes, L., \& Blakemore, S. J. (2020). Peer influence in adolescence: public-health implications for covid-19. Trends in Cognitive Sciences, 24(8), 585587. https://doi.org/10.1016/j.tics.2020.05.001

Badan Pusat Statistik. (2020). Hasil survei sosial demografi dampak covid-19. BPS RI.

Brannon, L., Feist, J., \& Updegraff, J. . (2018). Health psychology: an introduction to behavior and health. Cengage Learning.

Gorbalenya, A. E., Baker, S. C., Baric, R. S., de Groot, R. J., Drosten, C., Gulyaeva, A. A., Haagmans, B. L., Lauber, C., Leontovich, A. M., Neuman, B. W., Penzar, D., Perlman, S., Poon, L. L. M., Samborskiy, D. V., Sidorov, I. A., Sola, I., \& Ziebuhr, J. (2020). The species severe acute respiratory syndrome-related coronavirus: classifying 2019-nCoV and naming it sars-cov-2. Nature Microbiology, 5(4), 536544. https://doi.org/10.1038/s41564-020-0695-z

Hudiyawati, D., \& Rizki, S. (2018). Pengetahuan berpengaruh terhadap kepatuhan dalam perawatan kaki pada klien diabetes melitus tipe II. (JKG) JURNAL KEPERAWATAN GLOBAL, 3(2), 66-74. https://doi.org/10.37341/jkg.v3i2.52

Kemenkes RI. (2020). Keputusan menteri kesehatan republik indonesia nomor hk.01.07/menkes/413/2020 tentang pedoman pencegahan dan pengendalian coronavirus disease 2019 (covid-19) (pp. 109-120). Kemenkes RI.

Martias, I., Pitriyanti, L., \& Aldo, N. (2020). Studi tingkat kepatuhan masyarakat provinsi kepulauan riau untuk melaksanakan social/physical distancing dalam upaya mencegah penyebaran virus covid-19. Jurnal Sulolipu: Media Komunikasi Sivitas Akademika Dan Masyarakat, 20(2).

Nuqul, F. (2016). Hubungan peran jenis dengan minat menjadi pemimpin. Psikolislamika, 3(2), 200-219.

Sampurno, M. B. T., Kusumandyoko, T. C., \& Islam, M. A. (2020). Budaya media sosial, edukasi masyarakat, dan pandemi covid-19. SALAM: Jurnal Sosial Dan Budaya Syar-I, 7(5). https://doi.org/10.15408/sjsbs.v7i5.15210

Sari, D. P., \& 'Atiqoh, N. S. (2020). Hubungan antara pengetahuan masyarakat dengan kepatuhan penggunaan masker sebagai upaya pencegahan penyakit covid-19 di ngronggah. Infokes: Jurnal Ilmiah Rekam Medis Dan Informatika Kesehatan, 10(1), 52-55. https://doi.org/10.47701/infokes.v10i1.850

Sari, W. Y. (2018). Perbedaan tingkat kepatuhan terhadap aturan antara santri putra dengan santri putri di pondok pesantren al-amien kota kediri. Etheses.

Utami, R. A., Mose, R. E., \& Martini, M. (2020). Pengetahuan, sikap dan keterampilan masyarakat dalam pencegahan covid-19 di dki jakarta. Jurnal Kesehatan Holistic, 
4(2), 68-77. https://doi.org/10.33377/jkh.v4i2.85

Wulandari, D. H. (2015). Analisis faktor-faktor yang berhubungan dengan kepatuhan pasien tuberkulosis paru tahap lanjutan untuk minum obat di rs rumah sehat terpadu tahun 2015. Jurnal ARSI, 2(1), 17-28.

Yanti, B., Wahyudi, E., Wahiduddin, W., Novika, R. G. H., Arina, Y. M. D., Martani, N. S., \& Nawan, N. (2020). Community knowledge, attitudes, and behavior towards social distancing policy as prevention transmission of covid-19 in indonesia. Jurnal Administrasi Kesehatan Indonesia, 8(2), 4. https://doi.org/10.20473/jaki.v8i2.2020.4-14

Yuniarti, R., \& Hartati, W. (2020). Pemantauan penyebaran virus covid-19 pada mahasiswa stia muhammadiyah selong menggunakan aplikasi google form. In Abdiku: Jurnal Pengabdian Kepada Masyarakat. http://publikasi.stkippgribkl.ac.id/index.php/JA/article/view/363

Zhang, M., Zhou, M., Tang, F., Wang, Y., Nie, H., Zhang, L., \& You, G. (2020). Knowledge, attitude, and practice regarding covid-19 among healthcare workers in henan, china. Journal of Hospital Infection, 105(2), 183-187. https://doi.org/10.1016/j.jhin.2020.04.012 